\title{
The Mechanism of How Integrated Marketing Communications Influence on the Chinese Online Customer's Repurchase Intention
}

\author{
Shin Kwangyong, Zhongtian Shen, Haekun Shin ${ }^{*}$, Shiyao Zhang, Ke Chen, Lijie Li ${ }^{*}$ \\ Business School, Nankai University, Tianjin, P. R. China \\ Email address: \\ skyin@nankai.edu.cn (Shin Kwangyong), 1144912566@qq.com (Haekun Shin), lansy.lansy@163.com (Lijie Li) \\ ${ }^{*}$ Corresponding author
}

To cite this article:

Shin Kwangyong, Zhongtian Shen, Haekun Shin, Shiyao Zhang, Ke Chen, Lijie Li. The Mechanism of How Integrated Marketing Communications Influence on the Chinese Online Customer's Repurchase Intention. Science Journal of Business and Management. Vol. 9, No. 1, 2021, pp. 26-38. doi: 10.11648/j.sjbm.20210901.13

Received: December 29, 2020; Accepted: January 19, 2021; Published: January 25, 2021

\begin{abstract}
The competition in the online shopping industry is becoming intense. Compared with creating new customers, improving customer stickiness and repurchase intention is more important for the long-term development of E-commerce enterprises. At the same time, with the development of information technology, e-commerce platforms have more multiple channels to communicate with consumers timely. Thus, Integrated Marketing Communication, which is a more effective marketing strategy to E-commerce platform, obtained more attention. The aim of this paper was to clarify the path of Integrated Marketing Communications influence on online customer's repurchase intention. We collected data by taking 514 questionnaires of e-commerce users who have experience of online shopping in China. This paper used SPSS22.0 and AMOS24.0 data processing software to study the relationship between Integrated Marketing Communications (IMC), and customer satisfaction and online customer's repurchase intention. The mechanism by which IMC worked in the relationship was also explored. The results showed that IMC has a significant positive effect on customer satisfaction, which has a significant positive effect on online customer's repurchase intention. Additionally, compared with the negative direct regulation, IMC positively regulates online customer's repurchase intention by improving online customer satisfaction experience indirectly. The online consumer satisfaction experience plays a significant mediating role of IMC and online customer's repurchase intention. This analysis is significant. It not only confirms the positive role of IMC in the field of E-commerce in China to increase customer's repurchase intention but also has a more comprehensive and accurate analysis of the path mechanism.
\end{abstract}

Keywords: Chinese E-commerce Websites, Customer Satisfaction, E-commerce Platform, Integrated Marketing Communications (IMC), Online Customer's Repurchase Intention, Relationship Quality

\section{Introduction}

Since the Internet appeared in China in 1996, B2C e-commerce transactions have showed a blowout-growth. From 2014 to 2018, the development speed of mobile e-commerce platforms entered an 'outbreak period', with a total transaction volume exceeding 35 trillion yuan at an annualised growth rates of more than $25 \%$ [83]. Specific to e-commerce platform, according to the 2020-2025 China Mobile E-commerce Industry Market Analysis and Forecast Research Report released by China Zhiyan Consulting, the transaction scale of top three e-commerce giants: Alibaba,
Jingdong and Pinduoduo in China reached 4.82 trillion, 1.68 trillion and 471.6 billion respectively in 2018. Meanwhile, the development of social e-commerce shows rapid growth. In 2018, the scale of social e-commerce is 1.14 trillion yuan, and it is expected to reach 3 trillion yuan by 2020 , accounting for about $31 \%$ of the Chinese online retail market. However, customers become more familiar with the target products as the rapid growth of e-commerce and brand endorsement ability are more valued by users. It can be concluded that the quality of products and service experience will receive more attention in the future. The form and quality of products and services on each platform are convergent because of the continuous 
development of the e-commerce platform itself [88]. The price war also resulted in the shrinking of platform profits. According to the data, profits would be generated by ordinary customers who shop online for at least four times. Therefore, how to promote re-consumption, to increase customer willingness to repurchase, to improve customer viscosity, and to provide individualization products and services become the key to the future competition of e-commerce platforms [52].

The theory of Integrated Marketing Communications (IMC) appeared in the late 1970s, which was discovered by enterprises to integrate advertising, public relations, and other promotional means to improve marketing effect significantly. Kotler defined IMC from the perspective of the enterprises, and believed that IMC is the integration and coordination of a company's various communication channels which can deliver clear, consistent and convincing information of the company and its products [47]. Coming into the 21 st century, the concept focusing on IMC has moved to customer oriented. From this point of view, it is believed that there are many kinds of contact points between enterprises and customers, which has improved the enterprise marketing effect [48]. Guided by customer needs and market changes, IMC adjusted and integrated with the ever-changing world to achieve the best marketing effect [46]. The theory updated itself constantly with the continuous development of e-commerce. The mainstream view of the IMC theory was transferred from integrating all marketing tools to deliver a "consistent voice", which is spreading a consistent brand positioning and brand image to customers. Then, the scope of IMC jumped out of the confines of enterprises and rosed to be a kind of strategy. In this period, all stakeholders' resources were integrated to deliver "a consistent voice" to customers. It is considered that the Internet was the best medium for the realization of IMC [35]. According to Shin's opinion, stakeholders only involve online retailers, online customers, and logistics enterprises in E-platform, which give full play to IMC advantages. Kim and Ganguly pointed out that the key advantage of the Internet is interactive potential, which plays a positive role in e-commerce [45]. However, because of the high inclusiveness of IMC and the shortage of internal indicators to measure the effectiveness of marketing communications, it is difficult to judge the effectiveness of this marketing strategy [72]. For another, the research of the conversion from IMC to the customer's repurchase intention is insufficient. In the study on repurchase intention, it is found that high quality of e-commerce services will promote the repurchase behavior of customers [58]. Intention to repurchase is a relatively reliable predictive criterion for customer's final purchasing behavior [41]. Therefore, the relationship between IMC and customer's repurchase intention remains to be clarified, especially in the context of $\mathrm{B} 2 \mathrm{C}$ e-commerce. The results of exploring related issues are still relatively small, so this study helps to clarify the path of IMC influence on customers repurchase intention.

In this study, IMC is defined as outside-in, customer-oriented, delivering consistent information to customers, enabling them to obtain a consistent experience and establishing a good mutually beneficial relationship. The idea of IMC is to take customer demand as the starting point, coordinate and integrate resources, and achieve marketing goals by forming a healthy and long-term mutually beneficial relationship with customers [54]. Therefore, delivering a comprehensive customer experience to customers with IMC was the ultimate goal based on customer perspective. Hall pointed out that marketing communication can enhance the effect of the customer experience in any different stages [27]. It was believed that customer are looking forward to receiving sufficient reasons to purchase before actually product experience occurred [80]. In the experience stage, marketing information added more value and meaning to the product. After experiencing the product, customers will summarize the marketing information they acquired in language, sight, and hearing. All in all, IMC maximizes customer's overall consumption experience of product brands in each stage of experience, thus increasing customer's repurchase intention. Therefore, this paper assumes that IMC has a positive impact on customer satisfaction with online consumption experience, which has a positive impact on customer's repurchase intention.

This study explores the impact of IMC on customer's repurchase intention and whether the degree of customer's satisfaction plays an intermediary role between the e-commerce platform and customers. This research mainly has the following contributions. First of all, previous studies mostly used qualitative research methods, such as expert interviews, in-depth interviews, small seminars, etc., to investigate the implementation and performance of IMC strategies, but the relationship between IMC and customer relationship quality was rarely discussed. Therefore, based on the perspective of online customers, this study integrates IMC, E-commerce platform and customer's repurchase intention into the same research framework, and adopts the empirical method based on quantitative research to study the IMC path of customer's repurchase intention systematically. On the basis of guaranteeing the systematisms and completeness of the research conclusions, it plays a certain supplementary role to the related theories. Second, through the review and research of relationship quality, this study believes that customers online consumption experience satisfaction will have a certain impact on customer's repurchase intention. Therefore, this study takes satisfaction as mediating variable between IMC and customer's repurchase intention so as to clarify the path that IMC plays.

\section{Literature Review and Hypothesis}

Integrated Marketing Communications and customer
satisfaction
Integrated Marketing Communications (IMC) is a more
effective marketing tool in the digital marketing environment,
which positively affects customer's re-purchasing decisions
$[63,66,75]$. IMC is different from traditional marketing tools.
The focus of IMC is not on the target turnover or target profit
of the company but on the main targets of stakeholders [62, 19,
$15,23,71]$. IMC builds its own image by influencing and
controlling resources, which in turn affects customer's


psychological perception [16].

Taking the brand of "Beijing Huangtaiji Jianbing" as an example, which was founded in 2012 and gained a huge success with the brand channel integration. The founder worked in Baidu, Google, and other Internet platforms successively and had no experience in catering. The founder took E-platform as the only sales channel and achieved an annual turnover of 5 million yuan only in 10 months. The reasons lay in the fact that IMC effectively integrated relative topics in a variety of Internet platforms such as Weibo space etc. New media and traditional media fully integrated all kinds of online sales channels to form a consistent impression "Huang Taiji" brand, thus leading to achieving customer satisfaction and repurchase intention for promotion [78]. It can be conclude that consistent voice from the Internet create a stronger image in consumers' purchasing experience than a message that delivers not highly consistent information. We can further conclude that the customers will generate a strong repurchase intention when they gains a consistent message through different communication tools [18, 43, 51].

At the same time, IMC tools can also provide customers with more comprehensive information, which can spread the value of products to customers preferably and improve the efficiency of sustainable use [70]. Through the IMC, customer experience achieved a positive effect. Customer experience was defined as a "journey" with the enterprise, which spans multiple contact points in its purchase cycle [81]. It is based on these contact points that IMC has a positive impact on customer's repurchase. Spreading a comprehensive buying experience to customers is a main function of the IMC [80].

Furthermore, the concept of IMC takes customer needs as the starting point for coordinating and integrating resources and functions and achieving marketing goals by forming a healthy long-term mutually beneficial relationship with customers [28]. Relevant scholars believe that relationship quality is the degree to which companies meet customer needs, and products or services that meet customer needs are necessary conditions for improving relationship quality [84]. The connotation of IMC theory has shown that there is a close relationship between IMC and customer relationship quality.

In addition, From a customer perspective, IMC has a significant positive impact on brand loyalty, customer perception, and brand imagination in the service industry (such as the hotel industry) [2]. This process of cognition and experience of services or brands is also a learning process for customers. This learning process can be applied to future purchases and consumption behaviors in the process of obtaining consumption. In other words, in the process of consumption, it not only played a role in purchasing decisions but also had a guiding significance for future purchases. Reid explored the relationship between the IMC process and brand achievements (such as brand awareness, brand loyalty, and sales) in the context of online audit services [29]. IMC can influence and control the meanings linked with the brand, and create and reflect the brand image, thus influencing the way consumers perceive the product [16].
As brand image is shaped in the consumers' experience through buying contacts, the consumer links the brand to both favourable and unfavourable concepts [44]. Additionally, IMC can create brand meaning in the consumers' opinions by strategically linking tangible and intangible brand associations with certain properties [44]. Israeli reported that repetition in marketing communications could be a signal of quality and, moreover, significant in creating and maintaining customer loyalty [34]. Similarly, Keller suggested that IMC can stimulate intense and active consumer-brand loyalty by facilitating a strong contacts between customers and the brand [44].

Beside, customer will have negative impact on the initial contacts about the brand if they receive inconsistent messages [20]. Therefore, from an individual perspective, one of the most important aims of IMC is to effectively generate and maintain brand equity through encouragement and reinforcement of brand relationships with the customers and prospects [3].

Finally, it is proved that IMC has a significant positive correlation with brand achievements through empirical testing. The study had proved the impact of IMC on customer satisfaction and the relationship between customers to a certain extent [60].

Based on the positive role of IMC theory in the field of the customer experience and brand maintenance, this study proposes the following hypotheses:

Hypothesis 1: IMC has a significant positive impact on online customer satisfaction.

Customer satisfaction and online customer's repurchase intention

Intention to repurchase is a subjective tendency of customers to consume goods or services of enterprises [24]. When a customer makes a purchase, he expects the item based on the price he paid to obtain the target item. If this expectation is finally satisfied, intention to repurchase will have occurred. At the same time, the more we expect to be satisfied, the stronger our intention to repurchase will be [12]. E-commerce service quality will directly promote customer behavior intention [58]. Some studies regard the overall service quality and customer satisfaction as double intermediaries. Finally, the empirical analysis shows that the dimensions, reliability, responsiveness, and trust of website design will affect the overall service quality and customer satisfaction. In turn, it is significantly related to customer's repeated purchase intention [49]. In addition, relevant scholars also believe that customer satisfaction can be divided into transaction satisfaction and cumulative satisfaction. The former points out that customer satisfaction is related to specific transaction behaviors, and the latter points out that customer satisfaction is formed in long-term interactions with enterprises. This overall evaluation is based on multiple purchases of products or services [39]. For instance, the atmosphere of restaurant and service performance constitute the customer's dining experience and make the customer feel delighted, relaxed, and satisfied. The sense of well-being felt at the hotel restaurant increased their intention to repurchase particularly, which affects 
a customer satisfaction and follow-up behavior, in order that customers have a higher intention to repurchase [50]. Perceived value can directly affect customer's intention to continue to buy. The higher the perceived value, the stronger intention to maintain the original product or service will be [86]. In the context of the explosive growth of e-commerce activities, system accessibility, security, service speed, and acceptance are the keys to customer's perceived utility value, while information diversity, service speed and acceptability is the key to hedonic value. Utilitarian and hedonistic values will lead to online customer satisfaction and significantly promote their intention to repurchase. These results indicate that customer's perceptions of utilitarian and hedonistic values increase their preference for specific online shopping sites. But the direct relationship between trust and intention to buy back online has not been statistically supported. Perceived ease of use positively affects trust and perceived usefulness, customer confirmation positively affects perceived usefulness and customer satisfaction, and trust, perceived usefulness, satisfaction, and perceived enjoyment positively affect customer's intention to repurchase [14]. System quality has a significant impact on hedonism shopping value, information quality has a significant influence on utilitarian shopping value, and service quality has a significant influence on both utilitarian shopping value and hedonic shopping value. Utilitarian shopping value, customer trust, and customer satisfaction have a direct positive effect on online customer's repurchase intention. Therefore, developing and controlling high-quality, high-reliability websites is an important issue for companies to survive, gain competitive advantage, and achieve long-term success [30]. Based on the above analysis, we propose the following hypothesis:

Hypothesis 2: There is a significant positive correlation between customer's online consumption experience satisfaction and their intention to purchase again.

\section{Mediation of Customer Satisfaction}

By reviewing the existing literature on customer satisfaction and customer's repurchase intention, this study finds that customer satisfaction with online consumption experience usually appears as an intermediary variable in recent studies and has a significant relationship with most customer's repurchase intention. The main difference between the Internet and other marketing communication lies in its interactivity [46]. Ivanov pointed out in their study that the influence of the Internet on IMC theory lies in the fact that the Internet is the best medium to realize IMC [35]. Meanwhile, It was believed that IMC can improve overall customer experience and bring online customer satisfaction [79]. Depending on the timing and the specific cause, satisfaction can be conceptualized in two aspects, called cumulative satisfaction (or overall satisfaction) and transaction-specific satisfaction. The so-called transaction-specific satisfaction referred to the fact that satisfaction is generated based on specific service experience or characteristics of specific service experience. When consumer satisfaction is based on positive emotions generated from the accumulated shopping experience in the past, it is called cumulative satisfaction or overall satisfaction. With the rapid development of $\mathrm{B} 2 \mathrm{C}$ businesses, customer satisfaction has also shifted to the category of electronic or online satisfaction.

"Customer use comments" is the main character of E-commerce, which increases the interaction in customer's purchasing behavior and makes customers feel comfortable in the process of consumption, and produces customer satisfaction ultimately. The research proved that eWOM (online comment experience), that is, communication, has a significant impact on customer's product attitude and behavioral intention [32]. Fazio and Zanna believed that buying attitude is based on the direct experience of the previous behavior of an object [21]. Compared with the indirect experience, the attitude formed by direct experience is more confident and persistent and has a firmer attitude when in the face of attack. These attitudinal characteristics contribute to the formation of attitudinal-behavioral consistency. As a result, a positive evaluation of products and services can be generated to achieve customer satisfaction. To some extent, the above researches reveal the driving effect of customer experience on customer satisfaction. E-commerce platforms can obtain the feedback data of consumer's satisfaction in real-time so as to improve sales behavior, manage customer experience, and thus improve the comfort level of customer's online shopping experience. Finally, the generation of customer's repurchase intention will be promoted by improving the level of customer satisfaction.

Therefore, this study believes that through the implementation of IMC, e-commerce platforms coordinated kinds of functions and various marketing tools to form a "consistent voice", which is conducive to quickly establish a brand image and improve the relationship between customers and e-commerce platforms.

The quality of relationships affects the customer's intention to repurchase. This study further hypothesized the following hypothesis.

Hypothesis 3: Onine Customer satisfaction plays a significant mediating role between IMC and online customer's repurchase intention.

IMC and online customer's repurchase intention

Does IMC has a significant direct impact on online customer's repurchase intention? We have a fourth hypothesis here.

IMC acts on contact points that existed in all aspects of shopping and thus enable consumers to have a consistent impression of the brand. Schultz has argued that the brand is the critical crucial to integrated marketing. The brand, in increasingly, is the central core of what consumers want and consider to be value [63]. The objective of brand communication has been to expose the online customer to a brand, whereby the effect can be largely maximized in terms of increased experience and higher satisfaction, so that the online customer will make a repurchase decision through contact points indirectly. Any exposure to the brand communication affects online customer satisfaction which can be measured by 
analyzing variables like brand awareness in terms of recall and recognition, favorability, strength and uniqueness of the brand associations in the consumer online experience. These dimensions affect other characteristics of brand congruity and relationships among the brand associations in online customer's experience for building a positive image [57].

For another aspect, the fundamental foundation of IMC is a consistent voice. This dimension refers to the communications activities that are intended to generate a very single positioning of a brand in its target market by delivering a consistent voice on various communications channels. This dimension emphasizes a clear and consistent image by unifying messages and coordinating various communications channels as one voice concept Nowak and Phelps's [55]. The aspect of IMC "continuity" consisting of two activities - (1) a psychological continuity with an image or a theme which is used consistently in all types of media and (2) a physical continuity in which a uniform slogan and the same trademark are consistently used in all types of media Sirgy [74]. This dimension of IMC requires the B2C marketing manager to develop a communications plan for the target market by strategically coordinating various messages to project a single image and by carefully unifying the execution of message delivery on different communications channels (e.g., advertising, public relations, direct marketing, sales promotion, etc.). Belch and Belch conceptualized the IMC as delivering the same voice consistently to the $\mathrm{B} 2 \mathrm{C}$ market through all marketing and promotional activities [8].

Finally, online customer's repurchase intention will be promoted. Customer experience occurs at the contact points. For online customers, the entire shopping trip included the following several parts: information search and sensory experience of display pages on online store, interactive interaction with online retailers, the general trust of online shopping experience, the experience of online comments, emotional experience of repurchase and post-purchase, those links constitute all-round key contact points of the journey [9]. Online customers make it clear that they will not repeat their purchases if they are not satisfied with any part of the process. This phenomenon leads us to stimulate that IMC increases the repurchase intention indirectly based on the contact points of the shopping journey.

Meanwhile, online customer experience covers five dimensions: sensory experience, emotional experience, trust experience, post-purchase experience, and online comment experience. In terms of sensory experience and emotional experience, Rose empirically confirmed that sensory and emotional experience did not have a significant direct impact on repurchase intention and customer satisfaction played a key mediating role [61]. Based on the above discussion, this study further puts forward hypothesis 4:

Hypothesis 4: IMC influences customer satisfaction through indirect channels to promote the repurchase intention, rather than directly acting on.

To sum up, we proposed the theory that IMC deliver a consistent voice to customers through an e-commerce platform and promote online customer satisfaction from five aspects, namely, communication tools and channels consistency, visual consistency, language consistency, brand image consistency, and long term consistency. Online customer experience runs through all the key contact points of the entire online shopping journey. According to the cognition-emotion-behavior theory, online customer's satisfaction emotion is generated, and indirectly affects customer's retention and generates repurchase intention. Based on the above discussions, the theoretical research model is established as shown in Figure 1.

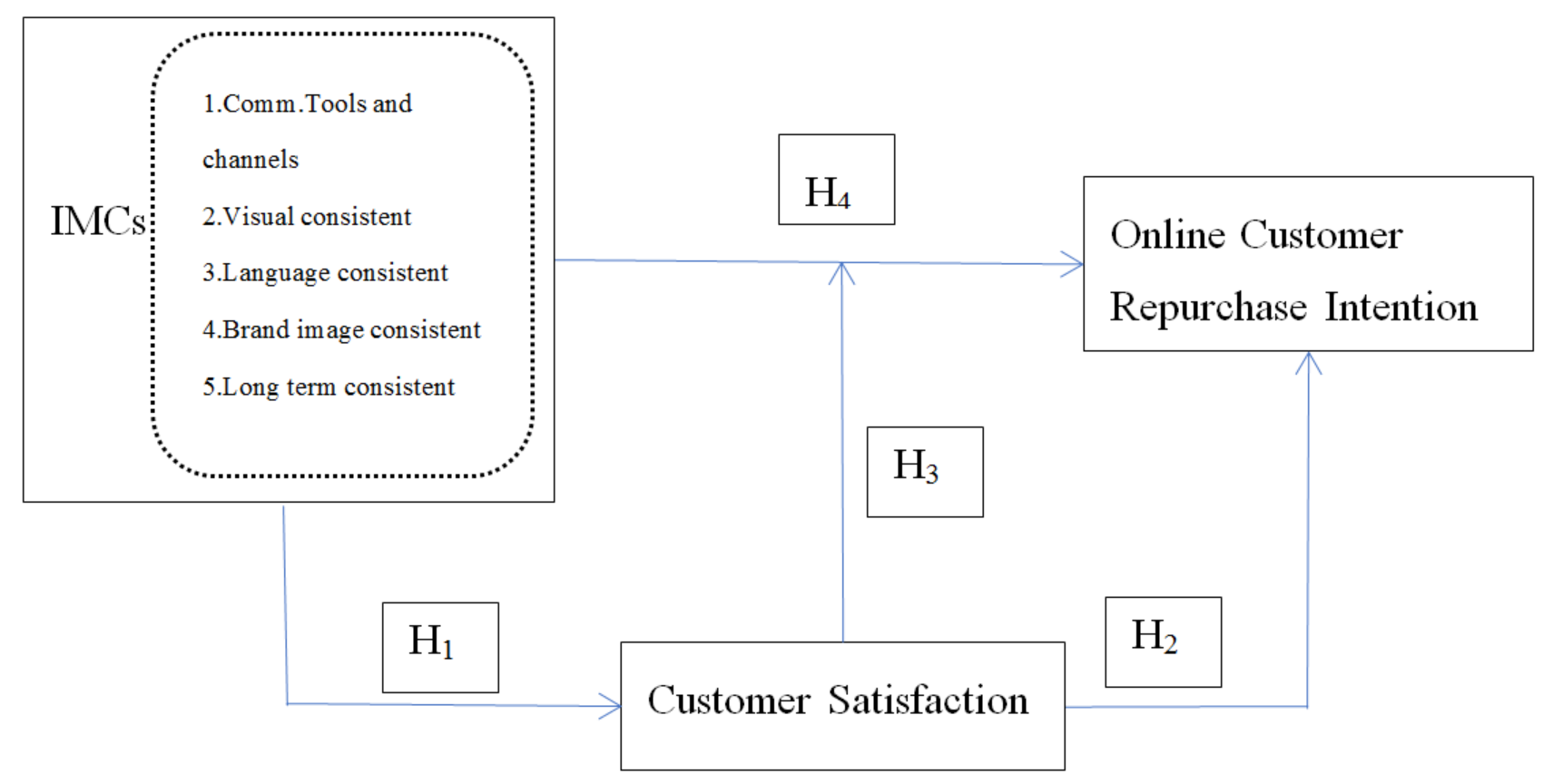

Figure 1. The conceptual model. 


\section{Methodology}

\subsection{Sample and Data Collection}

This study mainly focuses on e-commerce users who have an online shopping experience. 514 questionnaires were obtained by distributing questionnaires on We-Chat, QQ, and other online social channels. The survey expanded the scope of questionnaire distribution through the secondary communication of relatives and classmates. This study also expanded the regional diversity of sample data sources to reduce the possible impact of the same area on answering questions. This study used SPSS22.0 and AMOS24.0 data processing software to analyze and count the survey data. The specific analysis process mainly included descriptive statistical analysis, reliability and validity test, correlation test, structural equation model (SEM) path analysis, and Bootstrap Intermediate effect test method. First of all, the rationality of this questionnaire was judged by the demographic variables involved in the survey, and the frequency and proportion of the variables specially set for this study. Then the reliability and validity of the items designed by the questionnaire were judged by the reliability and validity test. Reliability analysis used Cronbach' $\alpha$ as the criterion. Validity analysis was divided into exploratory factor analysis (EFA) and confirmatory factor analysis (CFA). Exploratory factor analysis mainly analyzed the common factors of questionnaire items and the relevance of this factor to the corresponding item. Based on exploratory factor analysis, confirmatory factor analysis was used to observe the degree of fitting and differentiation of each latent variable, and determine whether the questionnaire items reliably express the latent variable. After completing the above basic analysis of the questionnaire and the model, the Pearson correlation coefficient was used to detect whether the correlation between various variables is significant, which is an important basis for verifying the hypothesis. Finally, structural equation modeling was used to analyze the path of the constructed model and verify the hypothesis, and AMOS software was used to test the mediation effect of the variables designed by the constructed model.

\subsection{Measures}

Dependent variable. The dependent variable is the online customer's intention to repurchase. In a mobile shopping environment, the online customer's repurchase intention refers to the intention to purchase a specific service or product more than once through the same channel. The repurchase intention scale used in this study mainly refers to the scales studied by scholars $[6,53]$. Based on the characteristics of E-commerce platform customers, 5 measurement items (R1-R4) are finally modified in Table 1.

Independent variable. The independent variable is IMC. Likert scale was used in this study to analyze the data. Respondents were asked to choose a value on a scale of 1-5 (1=I totally disagree, 5=I totally agree). Previous studies results on IMC were already very rich. Through the literature review, we found that although the scales involved in the measurement of this variable are different, they are more in line with the definitions and connotation of IMC, which means spreading a consistent voice to the outside. So in this study, 5 single dimension of IM were made [68]. An improvement on the previous IMC scale was shown in our study because of the specifically measurement, and its procedures were more stringent in methodology. The dimensions are numbered IMC1-IMC5 in table 1.

The IMC dimension measurement Scale was first proposed by Lee and Park in 2007, mainly focusing on product perception, image, and customer performance. Accordingly, Šrić proposed that IMC is to provide consistent image ideas through various communication channels and select the consistent image from five aspects to measure customer's IMC perception. Namely, communication tools and channels consistency, Visual consistency, language consistency, brand image consistency, and long term consistency.

Mediating variables. The intermediary variable is customer satisfaction. In the context of mobile shopping, customer satisfaction refers to the overall satisfaction that online customers obtain during the shopping process. This definition included the connotation of the comparison between actual and expectations. Therefore, the customer satisfaction scale used in this study mainly refers to the original scale of Maxham \& Netemeyer and Tsai et al. [53, 80]. The scale of this study is obtained through translation and sorting. There are 4 items from SAT 1 to SAT4 in Table 1.

Control variables. We controlled the following variables. First, we controlled for gender by measuring the online customer's repurchase intention. Second, age was controlled because young people may face more challenges in facing difference opportunities in E-commerce website due to their smaller experience and resource compared to the aged people. Third, we controlled for online customer's education because it may differentially encourage online customer to develop different choices. Finally, the profession was controlled because it can be a distinguishing factor for online customer to make a repurchase decision in Chinese e-commerce website.

\section{Data Analysis}

\subsection{Reliability and Validity}

The reliability analysis of each factor is shown in table 1, which is judged according to the value of Cronbach's $\alpha$ coefficient. Cronbach's $\alpha$ coefficient of each variable is greater than 0.7 . The Cronbach's $\alpha$ coefficient value of customer satisfaction and customer's repurchase wishes exceeds 0.9 , which indicated that, items in the scale are highly reliable and relevant, and have high internal consistency. Therefore, the result showed that the design of this questionnaire was more reasonable and reliable.

The results of the confirmatory factor analysis showed that the factor loadings for each item were between 0.6270 and 0.9413 . The AVE value of each latent variable was greater 
than 0.5 and the $C R$ value was also exceeds 0.5 . It can be founded that the scale of this study has good combination validity and all indicators meet the standards. At the same time, the square of the correlation coefficient between each variable is less than the average variance extraction rate index (AVE) of the variable, so the variables involved in this scale also have good discrimination validity.

Table 1. Measurement scales and properties.

\begin{tabular}{lll}
\hline Constructs/Measurement items & Cronbach's Alpha & Standardized loadings \\
\hline IMC & 0.872 & 0.460 \\
Comm. Tools and channels consistency & & 0.873 \\
Visual consistency & 0.897 \\
Language consistency & 0.790 \\
Brand image consistency & 0.856 \\
Long term consistency & 0.922 & 0.8270 \\
SAT & & 0.863 \\
Overall, the products and services of this e-commerce platform can meet my expectations & 0.884 \\
Overall, I am satisfied with the products and services provided by the e-commerce platform & 0.855 \\
I am satisfied after spending on this e-commerce platform & 0.857 \\
After spending on this e-commerce platform, I feel happy & 0.9223 \\
RI & 0.94 & 0.7479 \\
In the future, I will continue to consume on this e-commerce platform & & 0.905 \\
I tend to consume through this e-commerce platform & & 0.891 \\
I am likely to spend on this platform & & 0.910 \\
I really expect to spend on this e-commerce platform & 0.872 \\
\hline
\end{tabular}

Before hypothesis testing, confirmatory factor analysis was performed on all variables. Data were imported into the structural equation model constructed by AMOS to test the fitting degree of the model. The three-factor, double-factor and single-factor models were also tested in our study. The analysis results were shown in Table 2 . In the three-factor IMC structural equation model for online customer's repurchase intention, an acceptance criterion was less than 5 (RMSEA value $=0.075$ ). Because of the acceptable standard was less than 1, it was also easily concluded that the model fits well. The other four indicators $(\mathrm{GFI}=0.934$, IFI $=0.967$, TLI $=0.946, \mathrm{CFI}=0.967)$ all exceeded the acceptable standard of 0.9 , which indicated a good model fitting. Therefore, it could be seen that three-factor model has the most ideal fitting degree. Because creating and maintaining a consistent brand image is an important goal of IMC, three items were created to capture these activities.

Table 2. Discriminant validity test.

\begin{tabular}{|c|c|c|c|c|c|c|}
\hline Model & $\chi^{2 / \mathrm{d} f}$ & RMSEA & GFI & IFI & TLI & CFI \\
\hline Three-factor Model & 3.858 & 0.075 & 0.934 & 0.967 & 0.959 & 0.967 \\
\hline Two-factor Model & 17.191 & 0.178 & 0.679 & 0.810 & 0.767 & 0.809 \\
\hline Single-factor Model & 39.319 & 0.273 & 0.473 & 0.542 & 0.450 & 0.541 \\
\hline Criteria & $1<<5$ & $<0,08$ & $>0.9$ & $>0.9$ & $>0.9$ & $>0.9$ \\
\hline
\end{tabular}

Note: The three-factor model is IMC, SAT, RI; the two-factor model is IMC, SAT+RI; the one-factor model is IMC+SAT+RI

\subsection{Descriptive Statistics and Correlation Analysis}

The mean and standard deviation of variables were shown in Table 3. It can be seen that descriptive statistical analysis and correlation tests were carried out for each major variable, and the mean value and standard deviation of IMC were 3.535 and 1.005 respectively. The mean satisfaction degree and standard deviation of customer's online consumption experience were 4.007 and 0.727 respectively. The mean value and standard deviation of online customer's repurchase intention were 4.220 and 0.748 respectively. IMC is positively correlated with customer satisfaction degree of online consumption experience $(=0.221, \mathrm{P}<0.01)$, and customer satisfaction degree of online consumption experience is positively correlated with customer buyback intention $(=0.249, \mathrm{P}<0.01)$. These results show that the study has passed the relevant tests, which provides preliminary evidence for the intermediary test and lays an empirical foundation for the next step of path analysis.

Table 3. Descriptive statistical and correlation test.

\begin{tabular}{|c|c|c|c|c|c|c|c|c|c|}
\hline Variables & $\mathbf{M}$ & S. D & 1 & 2 & 3 & 4 & 5 & 6 & 7 \\
\hline 1. IMC & 3.535 & 1.005 & 0.792 & & & & & & \\
\hline 2. Customer Satisfaction & 4.007 & 0.727 & $0.221 * * *$ & 0.960 & & & & & \\
\hline 3. Repurchase Intention & 4.220 & 0.748 & $0.169 * * *$ & $0.249 * * *$ & 0.970 & & & & \\
\hline 4. Gender & 1.621 & 0.486 & $0.100^{*}$ & -0.013 & 0.009 & & & & \\
\hline 5. Age & 2.403 & 1.101 & $0.191 * *$ & 0.057 & -0.047 & $-.093 *$ & & & \\
\hline 6. Education & 2.839 & 0.891 & $0.174 * *$ & -0.010 & -0.037 & 0.025 & $0.279 * *$ & & \\
\hline 7. Profession & 2.302 & 1.275 & $0.108^{*}$ & 0.005 & -0.016 & -0.029 & $0.381 * *$ & $0.365^{* *}$ & \\
\hline
\end{tabular}

Note: $* \alpha=0.1 ; * * \alpha=0.05 ; * * * \alpha=0.01$; Numbers in bold on the diagonal indicate the square root of AVE. 


\subsection{Hypothesis Testing}

Referring to Ubeda-Garcia et al. and Zaki, the bootstrapping method (5000 samples with bootstrap confidence interval of 95\%) was used to examine the influence of IMC on entrepreneurial performance [82, 89]. The results were shown in table 4 and figure 2: the overall impact of IMC on repurchase intention is significant (0.153), while the direct impact is not significant $(-0.020)$. These results indicate that the influence of internal integration on repurchase intention is mediated. Therefore, the mediation mechanism between IMC and customer satisfaction with online consumption experience needs to be further tested, and the results are shown in Table 4 . The confidence interval of the path coefficient $(0.256)$ between IMC and customer online consumption experience satisfaction is [0.196, 0.317], excluding zero. Therefore, IMC has a significant positive impact on customer satisfaction degree of the online consumption experience, which supports hypothesis1. The confidence interval of the path coefficient ( 0.673 ) between online customer's online consumption experience satisfaction and their intention to purchase again is $[0.599,0.747]$, excluding zero. Therefore, customer satisfaction with online consumption experience has a significant positive impact on repurchase intention, which supports hypothesis 2 . At the same time, the IMC direct impact on online customer's repurchase intention (-0.02) with a confidence interval of [-0.075, 0.035], indicating that IMC direct impact on customer buyback was not significant. Hypothesis 4 was supported. Besides, it is further explained that the intermediary relationship between IMC and online customer's repurchase intention (namely, hypothesis 3 ) needs to be further demonstrated.

It can be seen from Figure 2 and Table 5 that the mediating effect of IMC with indirect influence on customer's repurchase intention is 0.173 . The confidence interval is $[0.113,0.240]$, excluding zero. The mediating effect of IMC on the direct impact of customer buyback is 0.153 with a confidence interval of $[0.113,0.240]$, excluding zero. This indicates that, compared with the direct regulation of IMC on online customer's repurchase intention, IMC has an indirect way to improve online customer satisfaction experience (MMP1, MMP2 =0.173), significantly positively adjusted the repurchase intention. The online consumer satisfaction experience plays a significant mediating role. Therefore, the mediating effect of managers' attitude to risk is significant, and hypothesis 3 is supported.

Table 4. Effects on dependent variables.

\begin{tabular}{lllll}
\hline Dependent Variables & Independent Variables & T-Value (Bootstrap) & Direct Effect & Percentile 95\% Confidence Intervals \\
\hline Customer Satisfaction (R2=0.1355 ) & IMC & 8.292 & $0.256^{* * *}$ & {$[0.196,0.317]$} \\
Repurchase Intention (R2=0.0441) & IMC & 4.570 & $0.153^{* * *}$ & {$[0.087,0.219]$} \\
& IMC & -0.707 & -0.020 & {$[-0.075,0.035]$} \\
& Customer Satisfaction & 17.884 & $0.673^{* * *}$ & {$[0.599,0.747]$} \\
& Control Variabel ${ }^{\text {ss }}$ & T-Value (Bootstrap) & Coefficient & Percentile 95\% Confidence Intervals \\
Repurchase Intention (R2=0.0441) & Gender & 0.226 & 0.012 & {$[-0.094,0.118]$} \\
& Age & -1.856 & -0.049 & {$[-0.102,0.003]$} \\
& Education & -0.288 & -0.009 & {$[-0.071,0.053]$} \\
& Profession & 0.621 & 0.014 & {$[-0.031,0.059]$} \\
\hline
\end{tabular}
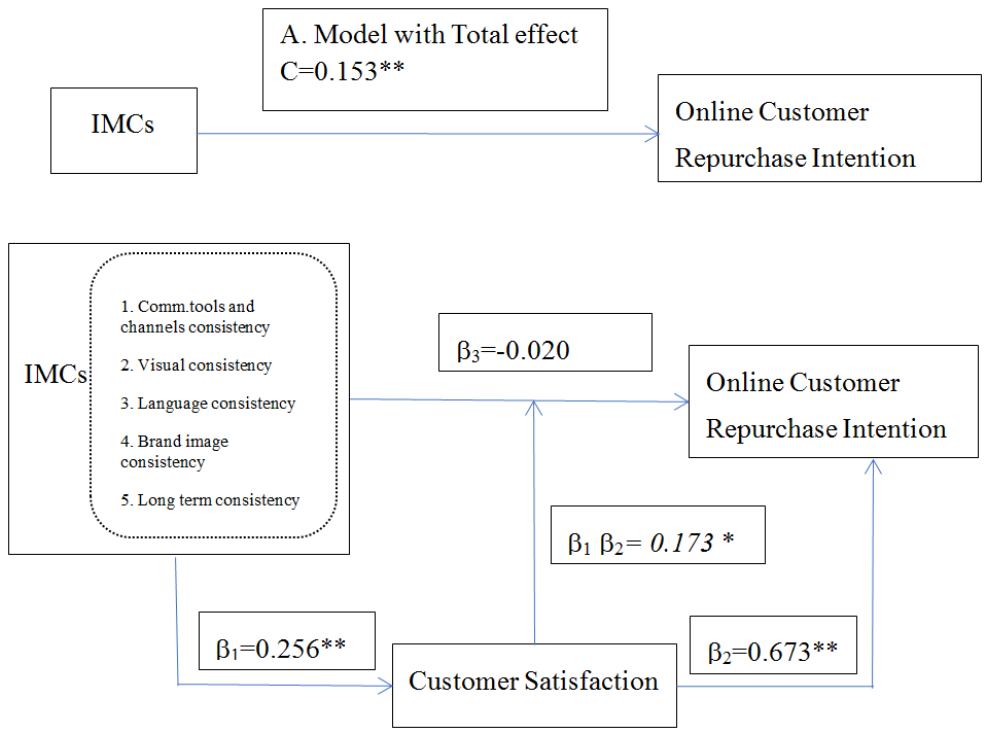

Figure 2. Results three-path mediation model.

$\mathrm{H} 1: \mathrm{IMC} \rightarrow$ repurchase Intention $=0.020 \mathrm{~ns}$

H2: IMC $\rightarrow$ Customer Satisfaction $\rightarrow$ repurchase Intention $=\beta_{1} \beta_{2}=0.173 *$

Note: $* * * \mathrm{p}<0.05 ;{ }^{*} \mathrm{p}<0.01 ; * * * \mathrm{p}<0.001 ;{ }^{\text {n }}$ Not significant (based on $\mathrm{t}(4999)$ one-tailed test 
Table 5. Summary of mediating effect test.

\begin{tabular}{lllll}
\hline & Effect & BootSE & BootLLCI & BootULCI \\
\hline Indirect Effect & 0.173 & 0.032 & 0.113 & 0.240 \\
Direct Effect & -0.020 & 0.034 & -0.084 & 0.047 \\
Total Effect & 0.153 & 0.037 & 0.082 & 0.226 \\
\hline
\end{tabular}

\section{Discussion}

Based on the perspective of E-commerce in China, this study constructs an IMC model, in which influences online customer's repurchase intention through customer satisfaction with online consumption experience. Customer satisfaction degree of online consumption experience plays an intermediary role in the relationship between the two, and the corresponding hypothesis was proposed and verified. The experimental results showed that IMC positively affects the satisfaction degree of customer's online consumption experience (Hypothesis 1). Customer satisfaction positively influences the buyback intention of a generation of customers (Hypothesis 2). At the same time, the mediating effect of customer satisfaction is also significant (hypothesis 3). IMC has no significant direct effect on online customer's repurchase intention (Hypothesis 4). IMC for customers means that the information obtained in each channel is very consistent, and in the process of obtaining such information, customers already have an initial impression of this e-commerce platform. When the customer's actual purchase experience of the business platform reaches or even exceeds his or her expectations, it will cause customer satisfaction. This satisfaction creates trust in the brand, so the same choice will occur in the next shopping choice. This study has confirmed that IMC mediates online customer's repurchase intention through customer satisfaction intermediately. In terms of online shopping situation, online customer satisfaction has played an important intermediary role, which has further confirmed the point of view that online customer's repurchase intention will produce customer retention, and above all, this is based on the satisfaction [5].

\section{Theoretical Implication}

This study has been clear about the mechanism of IMC to promote the brand image so as to improve the repurchase intention. It also enriches the theory of IMC, expands the understanding of IMC in terms of consistency of image. IMC is verified from the level of organization to improve online customer satisfaction so as to improve customer's repurchase. It not only confirms the positive role of IMC in the field of E-commerce in China to increase customer's repurchase intention but also has a more comprehensive and accurate analysis of the path mechanism. It also provides a new way of exploring the interactive communication of integrated marketing on the construction of word of mouth in e-commerce. At the same time, this study also provides a referable frame for further understanding of the influence mechanism of IMC to increase customer's repurchase rates.
This study promotes the adaptability of the IMC to the current marketing environment and provides new insights into the theory.

\section{Practical Implication}

This study also provides practical guidance for the application of IMC. Firstly, it is necessary to establish an internal organization and operation system suitable for IMC to enhance the consistency and synergy of brand communication. The implementation of IMC requires a set of efficient and consistent objectives and smooth communication with the internal operating system to provide strategic support. In the form of IMC implementation, the e-commerce platform needs to manage the entire marketing process and promote all employees to participate in the marketing process, so both cross-functional and cross-departmental participation are needed.

Secondly, taking the consumer as the center and expanding own marketing means were necessary. Online retailers should not only aim to improve customer satisfaction but also be oriented by customer delight. E-commerce is the product of the maturing of information and communication technologies. Therefore, e-commerce platforms should make use of these channels to constantly expand marketing methods and forms. We can innovate marketing models, improve marketing efficiency, and finally integrate customer's lives by using appropriate marketing methods in different media. If e-commerce platforms spread their own consistent information through various channels, they can shape their own image better and faster and finally win the favor and satisfaction of customers.

In addition, the use of cartoons, such as e-commerce platforms for their own slogans or logos, is also a special form of marketing. Transforming ice-cold characters into cartoon characters suitable for all ages can speed up the spread of information. For example, three squirrels animated their brand image and let three cartoon squirrels speak for themselves. In addition, three squirrels have been made into cartoons and shown on websites and advertisements. In this way, the distance between the customer and the e-commerce platform is greatly shortened, thus improving the satisfaction degree of the customer's online consumption experience. The same example could be found in Jingdong's Happy Dog. They regard the happy dog as the communication channel of their brand information, so as to obtain customer satisfaction and customer trust.

E-retailers should also focus on expanding their brand portfolios, emphasizing diversity, and monetary value in exchanges [22]. In addition, e-retailers need to promote interaction opportunities on the site, not only between existing 
customers and the company (for example, through real-time text chat) but also with potential customers (for example, through online communities), as these tools can increase customer loyalty.

Thirdly, e-platforms should be aware that word of mouth communication is the most effective tool in IMC. On e-commerce platforms, word of mouth has turned into "Weibo" and other communications integrated with the Internet media. After broadening the way, the enterprise should maintain good customer relationship in word-of-mouth communication, which becomes the foundation of the healthy development of the enterprise.

\section{Limitations and Future Research}

The questionnaires designed in this institute are all distributed through online social media (such as QQ, WeChat, etc.) and there are deficiencies in multi-parties, which makes the data inaccurate to reflect the psychology of the interviewee. In addition, unanswered questionnaires could affect the accuracy of the research. At the same time, although the sample size obtained in this study had up to 514 questionnaires, it is mainly based on the staff aged 26-45, and the academic qualifications of the respondents are mostly concentrated on undergraduates. The limitations exist in the fact that the capabilities of users have limited consumption in e-commerce platforms.

This study proposed the question "Before answering the questionnaire, please select the shopping site that you choose most frequently for daily shopping, and use this as the basis to answer the next questions" in JD.com and Pinduoduo. However, statistical results show that more than $70 \%$ of customers chose Taobao and used Taobao as the basis for answering the questionnaire. Therefore, the conclusion of this study has limitations in applicability to other platforms.

Therefore, based on the limitations of this study mentioned above, a future study can expand the diversity of respondents' usage of e-commerce platforms and the characteristics of respondents themselves so as to increase the representativeness of the sample. At the same time, a combination of online and offline is adopted. The questionnaire can be modified offline to improve the intelligibility of the questionnaire based on the responses and questions of the interviewees, thereby improving the accuracy of the sample data. In terms of model design, this study draws on previous studies and divides IMC into single-dimensional variables. In the future, more dimensional divisions suitable for exploring the design can be explored. At the same time, this study takes repeated purchase intention as the dependent variable, and the process of converting from repurchase intention to purchase behavior can also be further explored.

\section{Conclusions}

The influence mechanism of the Integrated Marketing Communications (IMC) has always been highly concerned because of its high efficiency in online retail market. The conceptual model was build and online customer satisfaction plays a significant mediating role between and online customer's repurchase intention. IMC influences customer's satisfaction through indirect channels to promote the repurchase intention, rather than directly acting on. This study enriches related theories, and puts forward relevant suggestions for the actual situation. The model can be further complicated and be explored more specific paths in future study.

\section{Acknowledgements}

This paper is supported by Tianjin Philosophy and Social Science Foundation, Research on the Effect of IMC on Marketing Communication of Large-scale Shopping Websites (Project No.: TJGL18-004).

\section{References}

[1] Amoako, G. K., Kutu-Adu, S. G., Caesar, L. D., Neequaye, E. 2019. "Relationship marketing and repurchase intention in Ghana's hospitality industry: an empirical examination of trust and commitment." Journal of Relationship Marketing 18 (13): $1-31$.

[2] Amri, S., Nurkhalis. 2018. "Online Shops Integrated Marketing Communication in Indonesia (Comparison Study on Trading Service in Web World)." Advances in Social Science, Education and Humanities Research, 1st Aceh Global Conference (AGC 2018) 292: 77-84.

[3] Anantachart, S., 2004. "Integrated marketing communications and market planning: their implications to brand equity building." Journal of Promotion Management 11 (1): 101125 .

[4] Andreasen, A. R. 1965. Attitude and Consumer Behavior: A Decision Model in New Research. Berkeley, CA: Institute of Business and Economic Research. University of California.

[5] Anderson, R. E., Srinivasan, S. S. 2003. "E-satisfaction and e-loyalty: a contingency framework." Psychology \& Marketing 20 (2): 123-138.

[6] Bagozzi, R. P., Lee, K. H., Van Loo, M. F. 2001. "Decisions to donate bone marrow: The role of attitudes and subjective norms across cultures." Psychology \& Health 16 (1): 29-56.

[7] Beard, Fred K. 1996. "Integrated Marketing Communications: New Role Expectations and Performance Issues in the Client-Ad Agency Relationship?" Journal of Business Research 37 (3): 207-215.

[8] Belch, G. E., Belch, M. A. 1993. Introduction to Advertising and Promotion: An Integrated Marketing Communications Perspective. Homewood, IL: Irwin Professional Publishing.

[9] Belch, G., Belch, M. 2009. Advertising and Promotion: An Integrated Marketing Communications Perspective. New York: McGraw-Hill Irwin.

[10] Blackston, M. A. 1992. "Brand with an Attitude: A Suitable case for treatment." Journal of the Market Study Society 34 (3): 231-241. 
[11] Caemmerer, B. 2009. "The planning and implementation of integrated marketing communications." Marketing Intelligence \& Planning 27 (4): 524-538.

[12] Cardozo, R. N. 1965. "An Experimental Study of Customer Effort, Expectation, and Satisfaction.” Journal of Marketing Research 2 (3): 244-249.

[13] Chen, S. C., Liu, M. L., Lin, C. P. 2013. "Integrating Technology Readiness into the Expectation-Confirmation Model: An Empirical Study of Mobile Services." Cyberpsychology Behavior and Social Networking 16 (8): 604-612.

[14] Chou, S. W., Hsu C. 2016. "Understanding online repurchase intention: social exchange theory and shopping habit." Information Systems and e-Business Management 14 (1): 19-45.

[15] Clark, Bruce H. 1999. "Marketing Performance Measure: History and Interrelationships." Journal of Marketing Management 44 (8): 711-732.

[16] Cobb-Walgren, C. J., Ruble, C. A., Donthu, N. 1995. "Brand Equity, Brand Preference, and Purchase Intent." Journal of Advertising 24 (3): 25-40.

[17] Davis, F. D., Bagozzi, R. P., Warshaw, P. R. 1989. "User Acceptance of Computer Technology: A Comparison of Two Theoretical Models." Management Science 35 (8): 982-1003.

[18] Dewhirst, T., Davis, B. 2005. "Brand strategy and integrated marketing communications: A case study of player's cigarette brand marketing." Journal of Advertising 34 (4): 81-92.

[19] Duncan, T., Moriarty, S. E. 1998. "A Communication-Based Marketing Model for Managing Relationships." Journal of Marketing 62 (4): 1-13.

[20] Ehrenberg, A. S. C., Barnard, N., Kennedy, R., Bloom, H. 2002. "Brand advertising as creative publicity." Journal of Advertising Research 42 (4): 7-18.

[21] Fazio, R. H., Zanna, M. P. 1981. "Direct experience and attitude-behavior consistency in advances in experimental social psychology." Advances in Experimental Social Psychology 14: 161-202.

[22] Fehrnstrom, M., Rich, D. M. 2009. "Using Events to Drive an Integrated Marketing Model.” Journal of Integrated Marketing Communication 31-37.

[23] Fill, Chris. 2001. "Essentially a Matter of Consistency: Integrated Marketing Communications." The Marketing Review 17 (12): 409-425.

[24] Fishbein, M., Ajzen, I., Belief, A. 1977. "Belief, attitude, intention, and behavior: an introduction to theory and study." Contemporary Sociology 6 (1): 130-132.

[25] Foster, J. 1990. "Working Together: How companies are integrating their corporate communications." Public Relations Journal 46 (9): 18-24.

[26] Ganguly, B., Dash S. B., Cyr, D. 2010. "The effects of website design on purchase intention in online shopping: the mediating role of trust and the moderating role of culture." International Journal of Electronic Business 8 (4-5): 302-330.

[27] Hall, B. 2002. "A new model for measuring advertising effectiveness." Journal of Advertising Research 42 (2): 23-31.

[28] Hennigthurau. T., Klee A. A. 1997. "The Impact of Customer
Satisfaction and Relationship Quality on Customer Retention: A Critical Reassessment and Model Development." Psychology \& Marketing 14 (8): 737-764.

[29] Homsud, S., Chaveesuk, S. 2014. "An integrated model of customer's repurchase intention in B2C e-commerce." International Conference on Information Technology \& Electrical Engineering. IEEE. October: 1-6.

[30] Hsieh, M. T., Tsao, W. C. 2014. "Reducing Perceived Online Shopping Risk to Enhance Loyalty: a Website Quality Perspective.” Journal of Risk Research 17 (2): 241-261.

[31] Huang, G. Q. 2019. "On the integrated marketing communications strategy under the new media." Decision Making Exploration 2 (11): 43.

[32] Huang, J. H., Hsiao, T. T., Chen, Y. F. 2012. "The effects of electronic word of mouth on product judgment and choice: the moderating role of the sense of virtual community." Journal of Applied Social Psychology 42: 2326-2347.

[33] Huber, F., Vollhardt, K., Matthes, I., Vogel, J. 2010. "Brand misconduct: consequences on customer-brand relationships." Journal of Business Study 63 (11): 1113-1120.

[34] Israeli, A. A., Adler, N., Mehrez, A., Sundali, J. A. 2000. "Investigating the use of advertising for communicating a hotel's strategic assets." Journal of Hospitality Marketing \& Management 7 (3): 23-37.

[35] Ivanov, A. E. 2012. "The Internet's impact on integrated marketing communications." Procedia Economics and Finance 3: 536-542.

[36] Jacoby, J., Chestnut, R. W. 1978. "Brand loyalty measurement and management." Journal of Marketing Study 15 (4): 121-149.

[37] Jenkinson A, Mathews B. 2007. "Integrated marketing and its implications for personalised customer marketing strategies." Journal of Direct, Data and Digital Marketing Practice 8 (5): 193-209.

[38] Jin, X. L., Zhou, Z., Lee, M. K. O. 2013. "Why Users Keep Answering Questions in Online Question Answering Communities: A Theoretical and Empirical Investigation." International Journal of Information Management 33 (1): 93-104.

[39] Jones, M. A., Suh, J. 2000. "Transaction - specific satisfaction and overall satisfaction: an empirical analysis." Journal of Services Marketing 14 (2): 147-159.

[40] Jones, Michael A., Mothersbaugh, David L., Beatty, Sharon E. 2000. "Switching barriers and repurchase intentions in services." Journal of Retailing 76 (2): 109-126.

[41] Jones, T. O. 1996. "Why Satisfied Customers Defect." Journal of Management in Engineering 73 (6): 11-12.

[42] Jung, Y., Kang, H. 2010. "User Goals in Social Virtual Worlds: A Means-end Chain Approach." Computers in Human Behavior 26 (1): 218-225.

[43] Keller, K. L. 2003. Strategic brand management: building, measuring, and managing brand equity. $2^{\text {nd }}$ ed. Upper Saddle River, NJ: Prentice Hall.

[44] Keller, K. L. 2009. "Building strong brands in a modern marketing communications environment." Journal of Marketing Communications 15 (2-3): 139-155. 
[45] Kim, S. 2011. "Web-Interactivity dimensions and shopping experiential value." Journal of Internet Business 9: 1-25.

[46] Kitchen, P. J., D. E. Schultz. 2001. Raising the corporate umbrella: Corporate communication in the 21st century. New York: Palgrave Macmillan.

[47] Kotler, P. 2000. Marketing management. $10^{\text {th }}$ ed. London: Prentice Hall International.

[48] Laric, M. V., Lynagh, P. M. 2010. "The Role of Integrated Marketing Communications in Sustainability Marketing." American Society of Business and Behavioral Sciences 17 (1): 108-119.

[49] Lee, G. G., Lin, H. F. 2005. "Customer perceptions of e-service quality in online shopping." International Journal of Retail \& Distribution Management 33 (2-3): 161-176.

[50] Lin, Shin-Yi, Chang Chia-Chi. 2020. "Tea for Well-Being: Restaurant Atmosphere and Repurchase Intention for Hotel Afternoon Tea Services." Sustainability 12 (3): 778.

[51] Madhavaram, S., Badrinarayanan, V., McDonald, R. E., 2005. "Integrated marketing communication and brand identity as critical components of brand equity strategy: a conceptual framework and research propositions." Journal of Advertising 34 (4): 69-80.

[52] Mathwick, C., Malhotra, N., Rigdon, E. 2001. "Experiential Value: Conceptualization, Measurement and Application in the Catalog and Internet Shopping Environment." Journal of Retailing 77 (1): 39-56.

[53] Maxham, J. G., Netemeyer, R. G. 2002. "Modeling customer perceptions of complaint handling over time: the effects of perceived justice on satisfaction and intent." Journal of Retailing 78 (4): 239-252.

[54] Duncan, T., Moriarty, S. 1997. Driving Brand Value: Using Integrated Marketing to Manage Profitable Stakeholder Relationships. New York: McGraw-Hill.

[55] Nowak, G., Phelps, J. 1994. "The Integrated Marketing Communications Phenomenon: An Examination of Its Impact on Advertising Practices and Its Implications for Advertising Research." Journal of Current Issues and Research in Advertising 16 (1): 49-66.

[56] Oliver, R. L. 1980. "A cognitive model of the antecedents and consequences of satisfaction decisions," Journal of Marketing Study 17 (4): 460-469.

[57] Panda, T. K. 2004. "Consumer Response to Brand Placements in Films: Role of Brand Congruity and Modality of Presentation in Bringing Attitudinal Change Among Consumers with Special Reference to Brand Placements in Hindi Films" South Asian Journal of Management 11 (4): 7-19.

[58] Parasuraman, A., Grewal, D. 2000. "The impact of technology on the quality-value-loyalty chain: a study agenda." Journal of the Academy of Marketing Science 28 (1): 168-174.

[59] Reid, Mike. 2002. "Building Strong Brands through the Management of Integrated Marketing Communications." International Journal of Wine Marketing 14 (3): 37-52.

[60] Reid, Mike. 2005. "Performance Auditing of Integrated Marketing Communications Actions and Outcomes." Journal of Advertising 34 (4): 41-54.
[61] Rose, S., Clark, M., Samouel, P. 2012. "Online customer experience in e-retailing: an empirical model of Antecedents and Outcomes." Journal of Retailing 88 (2): 308-322.

[62] Schultz, D. E. 1993. "Integrated marketing communications: maybe definition is in the point of view." Marketing News 27 (2): 17.

[63] Schultz, D. E., Schultz, H. 1998. "Transitioning Marketing Communication into the 21st Century." Journal of Marketing Communications 4: 9-26.

[64] Schultz, D. E., Kitchen, P. H. 2000. Communicating Globally: An Integrated Marketing Approach. London: Macmillan Business.

[65] Schultz, D. E. 2004. "Building an internal marketing management calculus." Interactive Marketing 6 (2): 111-129.

[66] Šerić, M., Saura, I. G. 2011. "Integrated marketing communications and information and communication technology in the hotel sector: An analysis of their use and development in Dalmatian first-class and luxury hotels." Journal of Retail \& Leisure Property 9 (5): 401-414.

[67] Šerić, M., Saura, I. G. 2012. "ICT, IMC, and brand equity in high-quality hotels of Dalmatia: an analysis from guest perceptions." Journal of Hospitality Marketing \& Management 21 (8): 821-851.

[68] Šerić, M., Saura, I. G., Ruiz-Molina, M. E. 2014. "How can integrated marketing communications and advanced technology influence the creation of customer-based brand equity? Evidence from the hospitality industry." International Journal of Hospitality Management 39 (2): 44-156.

[69] Sheth, J. N. B. I., Newman, B. L., Gross, B. L. 1991. "Why We Buy What We Buy a Theory of Consumer Behavior." Journal of Business Research 22 (3): 159-170.

[70] Shin, Kwang-Yong. 2013. The Executor of Integrated Marketing Communications Strategy: Marcom Manager's Working Model. Berlin, Heidelberg, Germany: Springer.

[71] Shin Kwang-Yong. 2014. Integrated Marketing Communications Strategy Management. Beijing, China: Tsinghua University Publishing.

[72] Simon, Torp. 2009. "Integrated communications: from one look to normative consistency." Corporate Communications: An International Journal 14 (2): 190-206.

[73] Singh, J., Saini, S. 2016. "Managing Consumer Loyalty through Acquisition, Retention and Experience Efforts: An Empirical Study on Service Consumers in India." Vision: The Journal of Business Perspective DOI: 10.1177/ 0972262916637264 .

[74] Sirgy, M. J. 1998. Integrated Marketing Communications: A Systems Approach. Englewood Cliffs, NJ: Prentice Hall.

[75] Škiltere, D., Bormane, S. 2018. "Integrated marketing communications as a business management tool in the context of sustainable development." Open Economics 1 (1): 115-123.

[76] Spreng, R. A., MacKenzie, S. B., Olshavsky, R. W. 1996. “A Reexamination of the Determinants of Consumer Satisfaction.” Journal of Marketing 60 (7): 15-32.

[77] Suki, N. M., Ramayah, T., Ly, K. K. 2012. "Empirical Investigation on Factors Influencing the Behavioral Intention to Use Facebook." Universal Access in the Information Society 11 (2): 223-231. 
[78] Su, Rong. 2016. "Research on Medea air conditioning integrated marketing communications under the new media environment." MBA Thesis, Nanjing: Nanjing University.

[79] Tsai, H. T., Huang, H. C., Jaw, Y. L., Chen, W. K. 2006. "Why online customers remain with a particular e-retailer: an integrative model and empirical evidence." Psychology and Marketing 23 (5): 447-464.

[80] Tsai, S. P. 2005. "Integrated marketing as management of holistic consumer experience." Business Horizons 48 (5): 431-441.

[81] Turner, Paul. 2017. "Implementing integrated marketing communications through major event ambassadors." European Journal of Marketing 51 (3): 605-626.

[82] Úbeda-García, M., Claver-Cortés, E., Marco-Lajara, B., Zaragoza-Sáez, P. 2016. "Toward Organizational Ambidexterity in the Hotel Industry: The Role of Human Resources." Cornell Hospitality Quarterly 57 (4): 367-378.

[83] Wang, Ying. 2020. "Characteristics of the fourth retail revolution and suggestions for the innovation and development of China's retail industry." Business Economy Research 3 (2): 12-15.
[84] Wang, Z., Kim, H. G. 2017. "Can social media marketing improve customer relationship capabilities and firm performance? Dynamic capability perspective." Journal of Interactive Marketing 39 (8): 15-26.

[85] Wen, C., Prybutok, V. R., Chenyan, X. U. 2011. "An integrated model for customer online repurchase intention." Journal of Computer Information Systems 52 (1): 14-23.

[86] Woodside, A. G., Frey, L. L., Daly, R. T. 1989. "Linking service quality, customer satisfaction, and behavioral intention." Journal of Health Care Marketing 9 (4): 5-17.

[87] Yeboah, A., Atakora, A. 2013. “Integrated Marketing Communication: How Can It Influence Customer Satisfaction?" European Journal of Business and Management 5 (2): 41.

[88] Yin Yanqi, Xin Hui. 2018. "The dilemma and countermeasures of the homogeneous competition in the e-commerce industry cluster." E-commerce 11 (8): 14-15.

[89] Zaki, Karam G. 2019. "Using the mixed methods research to model the hotel performance measurement in Egypt: An example from a hotel chain." Journal of Global Business Insight 4 (1): 18-33. 